\title{
CERKL wt Allele
}

National Cancer Institute

\section{Source}

National Cancer Institute. CERKL wt Allele. NCI Thesaurus. Code C104123.

Human CERKL wild-type allele is located in the vicinity of $2 q 31.3$ and is approximately 144

$\mathrm{kb}$ in length. This allele, which encodes ceramide kinase-like protein, is involved in

protecting cells from apoptosis in oxidative stress conditions. 